\title{
To compare and assess the clinical results of interlocking nailing in closed fractures of shaft of tibia by reamed and unreamead technique
}

\author{
Uppara RM. ${ }^{1 *}{ }^{*}$, Jonna N. ${ }^{2}$ \\ DOI: https://doi.org/10.17511/ijphr.2015.i1.02
}

1* Uppara RM, Assistant Professor, Department of Orthopedics, Rajiv Gandhi Institute of Medical Sciences, Kadapa, Andhra Pradesh, India.

2 Jonna N, Associate Professor, Department of Orthopedics, Rajiv Gandhi Institute of Medical Sciences, Kadapa, Andhra Pradesh, India.

Introduction: The successful use of unreamed nailing in patients with open tibial fractures has led some investigators to recommend this technique for closed fractures as well. Potential advantages of unreamed nailing over the reamed technique include shorter operative time, less blood loss and less disruption of the endosteal blood supply in patients with severe closed soft tissue injuries. Materials and Methods: This study consists of 34 cases of fracture both bones of leg, tibia treated by internal fixation with interlocking tibia, of which 17 cases are reamed and 17 cases are unreamed from August 2009 to July 2011, and followed upto November 2011. The study was conducted to assess the functional outcome and complications of reamed over unreamed nailing in tibial fractures. Results and Conclusion: In our study group there are no definitive criteria for using reamed and unreamed procedures, age groups are comparable and both procedures are applied randomly. 2 superficial infections are noted in unreamed cases and one deep infection noted in reamed cases. Knee pain complained in two cases of reamed nailing compared to one case of unreamed nailing. Odema of leg noted in one case of unreamed nailing. Earliest union noted in reamed nailing compared to unreamed.

Keywords: Reamed, Undreamed, Tibial Fractures

Corresponding Author

Uppara RM, Assistant Professor, Department of Orthopedics, Rajiv Gandhi Institute of Medical Sciences, Kadapa, Andhra Pradesh, India.
How to Cite this Article

To Browse

Uppara RM, Jonna N. To compare and assess the clinical results of interlocking nailing in closed fractures of shaft of tibia by reamed and unreamead technique. Public Health Rev Int J Public Health Res. 2015;2(1):9-14.

Available From

https://publichealth.medresearch.in/index.php/ijphr/

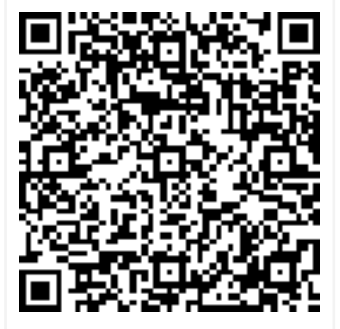
article/view/9

Manuscript Received 2015-03-15

Conflict of Interest No
Review Round 1 2015-03-16

Funding $\mathrm{Nil}$
Review Round 2 2015-03-29

Ethical Approval Yes
Review Round 3

Plagiarism X-checker $7 \%$
Accepted 2015-03-30

Note

(c) 2015 by Uppara RM, Jonna N and Published by Siddharth Health Research and Social Welfare Society. This is an Open Access article licensed under' a Creative Commons Attribution 4.0 International License https://creativecommons.org/licenses/by/4.0/ unported [CC BY 4.0]. 


\section{Introduction}

Tibia is the most commonly fractured long bone and the exposed anatomical location makes it vulnerable to direct blow and high-energy trauma as a result of motor vehicle accident [1]. Tibia has precarious blood supply with inadequate muscular envelope. Tibial fractures may be associated with compartment syndrome, vascular or neural injury [2]. The presence of hinge joints at the knee and the ankle, allows no adjustment for rotatory deformity after fracture. Because of high incidence of complications, management is often difficult.

The successful use of unreamed nailing in patients with open tibial fractures has led some investigators to recommend this technique for closed fractures as well. Potential advantages of unreamed nailing over the reamed technique include shorter operative time, less blood loss and less disruption of the endosteal blood supply in patients with severe closed soft tissue injuries. More over there is theoretical lowering of the incidence of fat embolism, by avoiding reaming.

Duwelius et al. [3] 1995 recommended unreamed nailing of closed tibial fractures with severe soft tissue injuries and reamed nailing of those without significant soft tissue injury. Gregory and Sanders [4], 1996 recommended unreamed nailing for polytraumatized patients with closed, unstable tibial fractures but found no advantage over reamed nailing for isolated, closed, unstable tibial fractures.

\section{Materials and Methods}

The aim of this prospective study is to compare and assess the clinical results of interlocking nailing in closed fractures of shaft of tibia by reamed and unreamead technique. The results will be tabulated, statistically arranged, and observation will be compared with similar studies published in literature. This is a prospective study done in SVRRGGH, Tirupati, to know the intraoperative, immediate post operative and late complications following closed interlocking intramedullary nailing. In this study, we have also tried to focus on the possible etiological factors for such complications.

\section{Results}

This study consists of 34 cases of fracture both bones of leg, tibia treated by internal fixation with interlocking tibia, of which 17 cases are reamed and 17 cases are unreamed from August 2009 to July
2011, and followed upto November 2011.

Age Distribution: The average age was 34.5 years (reamed) and 37.7 years (unreamed) with a range of 22 to 65 years.

Table 1: Age distribution of patients $(\mathrm{N}=34)$

\begin{tabular}{|l|l|l|l|l|}
\hline \multirow{2}{*}{ Age group } & \multicolumn{2}{|c|}{ No. of patients } & \multicolumn{2}{c|}{ Percentage (\%) } \\
\cline { 2 - 6 } & R & UR & $R$ & UR \\
\hline $20-39$ & 13 & 8 & 76 & 47 \\
\hline $40-59$ & 3 & 8 & 18 & 47 \\
\hline 60 Above & 1 & 1 & 6 & 6 \\
\hline Total & 17 & 17 & 100.0 & 100.0 \\
\hline
\end{tabular}

$\mathrm{X} 2=3.46 ; \mathrm{df}=2 ; \mathrm{P}=0.177 ;$ Nil Significant

Table 2: Sex Distribution of Patients $(\mathbf{N}=34)$

\begin{tabular}{|l|l|l|l|l|}
\hline \multirow{2}{*}{ Sex } & \multicolumn{2}{|c|}{ No. of patients } & \multicolumn{2}{c|}{ Percentage } \\
\cline { 2 - 6 } & R & UR & $R$ & UR \\
\hline Male & 15 & 13 & 88 & 76 \\
\hline Female & 2 & 4 & 12 & 24 \\
\hline Total & 17 & 17 & 100 & 100 \\
\hline
\end{tabular}

Fisher exact $P$ value $=0.65$ Nil Significant

Table 3: Distribution by side affected

\begin{tabular}{|l|l|l|l|l|}
\hline \multirow{2}{*}{ Side } & \multicolumn{2}{|c|}{ No. of patients } & \multicolumn{2}{c|}{ Percentage } \\
\cline { 2 - 5 } & R & UR & R & UR \\
\hline Right & 10 & 9 & 59 & 53 \\
\hline Left & 7 & 8 & 41 & 47 \\
\hline Total & 17 & 17 & 100 & 100 \\
\hline
\end{tabular}

$\mathrm{X}_{2}=0.12 ; \mathrm{P}=0.72 ;$ Nil Significant

Table 4: Level of Fracture in Patients

\begin{tabular}{|l|l|l|l|l|}
\hline \multirow{2}{*}{ Level of fracture } & \multicolumn{2}{c|}{ No. of patients } & \multicolumn{2}{c|}{ Percentage } \\
\cline { 2 - 5 } & R & UR & $R$ & UR \\
\hline $\mathrm{U} / 3$ & 0 & 0 & 0 & 0 \\
\hline $\mathrm{U} / 3-\mathrm{M} / 3$ & 3 & 4 & 18 & 24 \\
\hline $\mathrm{M} / 3$ & 6 & 3 & 35 & 18 \\
\hline $\mathrm{M} / 3-\mathrm{L} / 3$ & 7 & 7 & 41 & 40 \\
\hline $\mathrm{L} / 3$ & 1 & 3 & 6 & 18 \\
\hline Total & 17 & 17 & 100 & 100 \\
\hline
\end{tabular}

Statistics of Surgery: Surgery was done from 5 to 30 days after admission at an average of 15 days. All the cases were operated under spinal anaesthesia. Average duration of surgery was 45 minutes for reamed interlocking and 35 minutes for unreamed interlocking tibia.

Size of Nail: It depends upon the procedure with 8 to $9 \mathrm{~mm}$ for most of unreamed and 9 to $10 \mathrm{~mm}$ nail for reamed nailing. Length depends upon the patient. $10 \mathrm{~mm}$ nail was not used for unreamed and one nail of $8 \mathrm{~mm}$ size used for reamed nailing. 
Table 5: Size of Nail

\begin{tabular}{|l|l|l|l|}
\hline \multicolumn{1}{|c|}{ Nail diameter } & \multicolumn{1}{c|}{ Reamed } & \multicolumn{1}{c|}{ Unreamed } & Total \\
\hline 8 & 1 & 7 & 8 \\
\hline 9 & 10 & 10 & 20 \\
\hline 10 & 6 & 0 & 6 \\
\hline Total & 17 & 17 & 34 \\
\hline
\end{tabular}

$X 2=10.5, d f=2, P<0.005$ Significant

Table 6: Complication by Reamed \& Unreamed Category

\begin{tabular}{|l|l|l|l|}
\hline \multicolumn{1}{|c|}{ Complication } & \multicolumn{1}{c|}{ Reamed } & \multicolumn{1}{c|}{ Unreamed } & \multicolumn{1}{c|}{ Total } \\
\hline Infection & 1 & 2 & 3 \\
\hline Oedema & 0 & 1 & 1 \\
\hline Knee Pain & 2 & 1 & 3 \\
\hline Varus & 0 & 1 & 1 \\
\hline
\end{tabular}

$X 2=2.31 ; \mathrm{df}=3 ; \mathrm{P}=0.51 ;$ Nil Significant

Table 7: Union in months

\begin{tabular}{|l|l|l|l|l|}
\hline \multirow{2}{*}{ Union in months } & \multicolumn{2}{c|}{ No. of patients } & \multicolumn{2}{c|}{ Percentage } \\
\cline { 2 - 6 } & Reamed & Unreamed & Reamed & Unreamed \\
\hline $21 / 2$ & 1 & 0 & 6 & 0 \\
\hline 3 & 14 & 11 & 82 & 65 \\
\hline $31 / 2$ & 2 & 6 & 12 & 35 \\
\hline TOTAL & 17 & 17 & 100 & 100 \\
\hline
\end{tabular}

$X_{2}=3.36, d f=2.00 ; P=0.186$, Nil Significant

Table 8: Outcome by Age Group

\begin{tabular}{|l|l|l|l|l|l|l|l|l|}
\hline \multirow{2}{*}{ Age } & \multicolumn{2}{|c|}{ Excellent } & \multicolumn{2}{|c|}{ Good } & \multicolumn{2}{|c|}{ Fair } & \multicolumn{2}{c|}{ Poor } \\
\cline { 2 - 10 } & R & UR & R & UR & R & UR & R & UR \\
\hline $20-39$ & 9 & 4 & 3 & 3 & 0 & 0 & 1 & 1 \\
\hline $40-59$ & 2 & 1 & 1 & 4 & 0 & 2 & 0 & 1 \\
\hline 60 and Above & 1 & 0 & 0 & 1 & 0 & 0 & 0 & 0 \\
\hline
\end{tabular}

Table 9: Outcome by level of fractures

\begin{tabular}{|l|l|l|l|l|l|l|l|l|}
\hline \multirow{2}{*}{ Level of fracture } & \multicolumn{2}{|c|}{ Excellent } & \multicolumn{2}{c|}{ Good } & \multicolumn{2}{c|}{ Fair } & \multicolumn{2}{c|}{ Poor } \\
\cline { 2 - 9 } & R & UR & R & UR & R & UR & R & UR \\
\hline $\mathrm{U} / 3$ & 0 & 0 & 0 & 0 & 0 & 0 & 0 & 0 \\
\hline $\mathrm{U} / 3-\mathrm{M} / 3$ & 3 & 1 & 0 & 3 & 0 & 0 & 0 & 0 \\
\hline $\mathrm{M} / 3$ & 4 & 0 & 2 & 3 & 0 & 0 & 0 & 0 \\
\hline $\mathrm{M} / 3-\mathrm{L} / 3$ & 5 & 2 & 1 & 1 & 0 & 2 & 1 & 2 \\
\hline $\mathrm{L} / 3$ & 0 & 2 & 1 & 1 & 0 & 0 & 0 & 0 \\
\hline
\end{tabular}

Table 10: Outcome by Procedure

\begin{tabular}{|l|l|l|}
\hline \multicolumn{1}{|c|}{ Outcome } & \multicolumn{1}{c|}{ Reamed } & \multicolumn{1}{c|}{ Unreamed } \\
\hline Excellent & 12 & 5 \\
\hline Good & 4 & 8 \\
\hline Fair & 0 & 2 \\
\hline Poor & 1 & 2 \\
\hline
\end{tabular}

$X 2=6.55 ; d f=3.00 ; P=0.08 ;$ Nil Significant

Overall results were excellent in 17 cases (12 in reamed, 5 in unreamed), Good in 12 cases (4 in reamed, 8 in unreamed), Fair in 2 cases only in unreamed and poor in 3 cases( one reamed and 2 in unreamed ).

\section{Discussion}

Total 34 cases of tibia were treated by internal fixation, intra medullary nailing, by reaming and unreaming procedure, each 17 cases. They were followed for a period of 9 months within the study period of August 2009 to July 2011, and followed up to November 2011 . The purpose of the study was to evaluate the end result of treatment in these patients. No definitive criteria selected for reaming and unreaming procedure. They applied randomly.

\begin{tabular}{|c|c|c|c|c|c|c|}
\hline \multicolumn{7}{|c|}{ Level of fracture } \\
\hline Study & Proximal third & Junction of $\mathrm{P} / 3$ and $\mathrm{M} / 3$ & Middle Third & Junction of $\mathrm{M} / 3$ and $\mathrm{D} / 3$ & Distal third & Total \\
\hline Keating et al [5] & $3(4 \%)$ & $9(10 \%)$ & $36(41 \%)$ & $31(35 \%)$ & $9(10 \%)$ & $88(100 \%)$ \\
\hline Court Brown et al [6] & $2(7 \%)$ & - & $16(55 \%)$ & - & $11(38 \%)$ & $29(100 \%)$ \\
\hline Bone and Johnson et al [7] & $2(2 \%)$ & $5(5 \%)$ & $60(60 \%)$ & $17(17 \%)$ & $16(16 \%)$ & $100(100 \%)$ \\
\hline Present & 0 & $8(23.5 \%)$ & $8(23.5 \%)$ & $14(41 \%)$ & $4(12 \%)$ & $34(100 \%)$ \\
\hline
\end{tabular}

Size of the diameter of the Nail: The average diameter of the nail in our study was lesser than the keating et al's study as the western population had a better built than ours[5]. In the Whittle's study all patients underwent unreamed nailing which obviously fitted smaller diameter nails [8]. In our study both reamed and unreamed nailing had an average diameter of 8.5 and 9 respectively.

\begin{tabular}{|l|c|c|l|l|l|l|}
\hline \multirow{2}{*}{ Study } & \multicolumn{6}{|c|}{ Diameter of nail (mm) } \\
\cline { 2 - 8 } & 9 & 10 & 11 & Others (8-13) & Total & Average \\
\hline Keating et al [5] & 23 & 19 & 24 & 28 & 94 & 10.4 \\
\hline Whittle et al [8] & 18 & 13 & 0 & 16 & 47 & 8.9 \\
\hline Present & 20 & 6 & - & 8 & 34 & 8.97 \\
\hline
\end{tabular}

Reamed technique or not: The more recent studies as by Keating et al, Court Brown et al have shown same results with reamed technique with no significant increase in nonunion. 
Whittle's study had only unreamed ones as they believed that reaming destroys the endosteal supply which was affirmed in the experimental study by Schemitch et al on sheep models. In our study we have done a randomized selection of patients for either technique so that the influence of other factors like fracture pattern, site of fracture, age of patient, etc did not influence the final outcome.

\begin{tabular}{|l|l|l|l|}
\hline \multicolumn{1}{|c|}{ Study } & \multicolumn{1}{|c|}{ Reamed } & \multicolumn{1}{c|}{ unreamed } & \multicolumn{1}{c|}{ Total } \\
\hline Present & 17 & 17 & 34 \\
\hline Keating et al [5] & 50 & 44 & 94 \\
\hline Whittle et al [8] & 0 & 50 & 50 \\
\hline Court Brown et al [7] & 41 & 0 & 41 \\
\hline
\end{tabular}

\section{Conclusion}

The study was conducted to assess the functional outcome and complications of reamed over unreamed nailing in tibial fractures. In our study group there are no definitive criteria for using reamed and unreamed procedures, age groups are comparable and both procedures are applied randomly. 2 superficial infections are noted in unreamed cases and one deep infection noted in reamed cases. Knee pain complained in two cases of reamed nailing compared to one case of unreamed nailing. Odema of leg noted in one case of unreamed nailing. Earliest union noted in reamed nailing compared to unreamed.

\section{Reference}

01. [Article] [Crossref]

02. Frink M, Hildebrand F, Krettek C, Brand J, Hankemeier S. Compartment syndrome of the lower leg and foot. Clin Orthop Relat Res. 2010;468(4)940-50.

doi: $10.1007 / s 11999-009-0891-x \quad$ [Crossref]

03. Duwelius PJ, Schmidt AH, Rubinstein RA, Green JM. Nonreamed interlocked intramedullary tibial nailing- One community's experience. Clin Orthop Relat Res. 1995 Jun;(315)104-13.

[Crossref]

04. Gregory P, DiCicco J, Karpik K, DiPasquale T, Herscovici D, Sanders R. Ipsilateral fractures of the femur and tibia- treatment with retrograde femoral nailing and unreamed tibial nailing. J Orthop Trauma. 1996;10(5)309-16.

[Crossref]
05. Keating JF, O'Brien PJ, Blachut PA, Meek RN, Broekhuyse HM. Locking intramedullary nailing with and without reaming for open fractures of the tibial shaft- A prospective, randomized study. J Bone Joint Surg Am. 1997 Mar;79(3)334-41.

[Crossref]

06. Gregory P, Sanders R. The treatment of closed, unstable tibial shaft fractures with unreamed interlocking nails. Clin Orthop Relat Res. 1995 Jun;(315)48-55.

[Crossref]

07. Browner BD, Wiss DA. GK locking nail for the femur- The science and practice of intramedullary nailing. Philadelphia, Lee and Febyer. 1987.

[Crossref]

08. Whittle AP, Russell TA, Taylor JC, Lavelle DG. Treatment of open fractures of the tibial shaft with the use of interlocking nailing without reaming. J Bone Joint Surg Am. 1992 Sep;74(8)1162-71.

[Crossref] 